\title{
$\underline{\operatorname{articles}}$
}

\section{The Breadth and Depth of Small Business Human Resource Practices: Do High Performers Differ From Low Performers?}

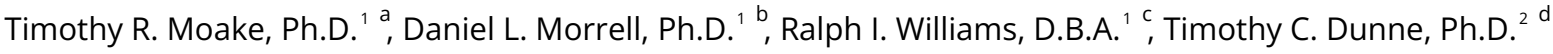 \\ 1 Jones College of Business, Middle Tennessee State University, ${ }^{2}$ College of Business and Economics, Boise State University \\ Keywords: Human resource practices, recruiting, small business, performance \\ https://doi.org/10.53703/001c.29835
}

\section{Journal of Small Business Strategy}

Vol. 31, Issue 5, 2021

\begin{abstract}
Often, small businesses do not possess the resources to have an HR department. In fact, small businesses are often led by busy managers from whom HR tasks drain time and energy. Therefore, small businesses need to understand how engagement in HR practices may impact firm performance. In this paper we add to existing knowledge by examining how higher performing small businesses differ from lower performing small businesses in terms of breadth (the number of HR practices engaged) and depth (engagement in active recruitment strategies) of HR practices. Our findings indicate that higher-performing small businesses tend to apply more breadth and depth in their HR approach than lower-performing small businesses.
\end{abstract}

\section{Introduction}

Scholars have long posited that high performing organizations engage in more human resource (HR) practices, and that HR practices are related to performance (Wright et al., 2005). HR practices include a wide range of activities, including recruiting, selection, training, compensation plans, and performance evaluation, to name a few (Mahto et al., 2018; Wright et al., 2005). While effective workforce management is essential for the success of all businesses, relative to larger businesses, smaller businesses are typically at a disadvantage in HR practice application. Characteristically, smaller businesses have little, if any, staff or resources totally focused on managing or enacting HR activities (Cardon \& Stevens, 2004; Coder et al., 2017; Klaas et al., 2000; Schultz et al., 1997). Large businesses, however, can spread costs associated with maintaining a dedicated HR department across many employees, an economy of scale small businesses lack (Klaas et al., 2000). Small business leaders must address multiple tasks and wear an assortment of hats (Williams et al., 2018). For these leaders, HR activities take time and effort away from focusing on other vital business areas (Klaas et al., 2000). Additionally, as employees form a small business' tacit knowledge base, small businesses tend to lack written procedures (Cardon \& Stevens, 2004; Ireland \& Webb, 2007; Kemelgor \& Meek, 2008). As such, small business leaders often tend to "muddle through" HR issues and "stumble upon ways to manage and retain per- sonnel” (Kemelgor \& Meek, 2008, p. 75). Yet, because each small business employee represents a significant percentage of the company's team (Froelich, 2004), small business HR practices are important, and therefore, HR research is vital to the small business field.

However, due to leader biases or simply a lack of HR experience or know-how, sometimes small business leaders are unable to implement effective HR practices. For example, some founders desire to maintain ultimate authority over hiring decisions, in which biases toward friends or family members may take precedence (Kotey \& Slade, 2005). Small business leaders may also recruit and hire based on personal likeability, more than relevant criteria such as technical skills (Cross, 1997). Employee recruiting and retention is a priority for small business leaders, yet small businesses often see recruiting and retention as a problem (Phillips \& Wade, 2008; Wade, 2016). In contemporary business literature, it is estimated that $60 \%$ of small business owners see recruiting skilled workers as their greatest challenge (Howart, 2013), which lends support to research findings where small business leaders identified personnel/recruiting as one of their most pressing issues (Lowry \& Chapman, 2000).

Researchers have explored relationships between small business HR approaches and various concepts, such as the following: the fit between HR practices and strategy (Schultz et al., 1997); the effect of HR practices on employee retention (Kemelgor \& Meek, 2008); small business leader

\footnotetext{
a Business and Aerospace Building, Murfreesboro, TN 37132-0001, USA, Timothy.Moake@mtsu.edu

b Business and Aerospace Building, Murfreesboro, TN 37132-0001, USA, Dan.Morrell@mtsu.edu

c Corresponding Author

Business and Aerospace Building, Murfreesboro, TN 37132-0001, USA, riwillia@mtsu.edu

d 1910 University Drive, Boise, ID 83725-1600, USA, timothydunne@boisestate.edu
} 
satisfaction with using professional employer organizations to handle HR activities (Klaas et al., 2000); the impact of small business leader characteristics on innovation (Mahto et al., 2018); interaction of entrepreneurial orientation (EO) with management HR control systems (Peake et al., 2019); and how human resource management (HRM), together with group culture, affects labor productivity (Patel \& Cardon, 2010). That said, few studies have explored the differences between the HR practices of high performing and low performing small businesses, which is the focus of this work (for an exception see Coder, Peake, and Spiller's (2017) study of high-performance work systems, intellectual capital, and firm performance).

In connecting HR practices to higher organizational performance, the present study seeks to provide findings with practitioner utility (Heneman \& Berkley, 1999). Furthermore, we aim to continue building the foundation of small business HR knowledge, which Cardon \& Stevens (2004) saw as lacking. From our review of the literature, we see the need for more small business knowledge development. This study explores how potential indicators of small business HR practices, particularly the breadth and depth of HR practices, connect with SME performance. In looking at breadth, we consider the number of HR practices in which organizations engage, and for depth, we consider the extent to which organizations engage in active recruitment processes. Active recruitment differs from passive recruitment in that with active recruitment, organizations vigorously seek suitable candidates. In contrast, passive recruitment entails a more traditional approach of posting job openings through various channels and waiting for candidates to apply for the open position (Motley, 2016). Because researchers have identified recruitment as a source of concern for many small businesses, analyzing small business recruitment strategies is of particular value (Phillips \& Wade, 2008; Wade, 2016). The next section reviews the literature related to potential linkages between HRM practices and small business performance.

\section{Literature Review HR Practices and Performance}

Both academics and practitioners agree that HR departments should add value to an organization (Ulrich \& Brockbank, 2005). This need has led to significant attention to research investigating the relationship between HR activities and firm performance (Wright et al., 2005). Before looking strictly at firm performance, it is worthwhile to examine, more broadly, how HR practices contribute to organizational success. For example, a substantial amount of research has examined numerous relationships among supportive HR practices and a variety of employee attitudes, finding positive associations between HR practices and employee job satisfaction, organizational commitment, employee engagement, and citizenship behaviors, and a negative relationship with turnover and counterproductive work behaviors (Agarwala, 2003; Ariani, 2013; Whitman et al., 2010; Yamazakia \& Petchdee, 2015).

As many conditions influence the relationships among the above-mentioned employee-related outcomes, a deep discussion is beyond the scope of the current paper.
Nonetheless, the general conceptualization is that when HR practices result in satisfied employees, they tend to be more committed, more engaged, and have lower intentions to quit (Aydogdu \& Asikgil, 2011; Russ \& McNeilly, 1995). Furthermore, high levels of organizational commitment and employee engagement tend to result in more productive employees (Deepa et al., 2014), which may positively affect firm performance (Markos \& Sridevi, 2010).

Additionally, the universality of some practices on individual attitudes has led to discoveries similar to those presented above. As evidence, Deepa et al. (2014) found a positive relationship between employee performance appraisals and job satisfaction, organizational commitment, citizenship behaviors, and engagement. Those outcomes together led to higher overall employee productivity. A significant amount of research supports those findings by indicating the positive effects of employee feedback. For instance, a result of decreased ambiguity, performance feedback is known to increase motivation (Kaymaz, 2011). While those factors related to employee attitudes were found to affect performance, another important HR function found to impact employee productivity was training and development. In fact, research found that training and development efforts help produce necessary skills and therefore lead to increased employee productivity in small businesses (Jayawarna et al., 2007; Mahto et al., 2018).

Beyond the effects of a single HR practice, research found that combined HR practices interact with employee job satisfaction to impact employee productivity and SME financial performance (Lai et al., 2017). Moreover, implementation of training and development, recruitment efforts, performance appraisals, and competitive compensation impacts sales growth in SMEs (Carlson et al., 2006; Chowdhury \& Schulz, 2020). Related, many SMEs use incentive compensation to attract talent and maintain motivation and morale (Carlson et al., 2006; Chowdhury \& Schulz, 2020). Nevertheless, there is still a lot we do not know about how HR practices broadly impact small business performance. The multiple positive relationships presented above suggest that companies focusing on a wide breadth of HR practices will outperform those that do not, resulting in our first hypothesis:

Hypothesis 1: Higher-performing small businesses will engage in more HR practices than lower performing companies.

\section{Active Recruitment and Performance}

For all companies, recruiting high-quality employees is of significant importance. However, for small businesses recruiting is even more important, yet it can be more challenging than it is for large firms. In fact, survey results from small and medium-sized firms report that, relative to other challenges, scarcity of qualified employees most threatens business growth (Williamson et al., 2002). Yet, there is a lack of evidence that small businesses regularly engage in deeper recruiting efforts, more than advertising the position through a newspaper ad, hanging a sign on the door, or posting something on social media (Carroll et al., 1999).

Research has shown that many small businesses prefer to fill vacancies using internal recruitment strategies (Desh- 
pande \& Golhar, 1994). Utilizing internal recruitment strategies, particularly employee referrals, often produces higher quality workers who are committed to the organization (Zottoli \& Wanous, 2000). When employees refer job seekers to open positions in their organization, those employees can provide relevant information about the job and the organization, which can help enhance person-organization fit. However, for many small businesses, using only internal recruitment sources limits the talent pool from which they can draw. As such, organizations need to engage in both internal and external recruitment to increase access to highly qualified employees (Erickson, 2001).

When smaller businesses turn to external recruiting, they face additional barriers to attracting job candidates because job seekers know little about the organization or have low perceptions of the organization's legitimacy (Williamson et al., 2002). Compared to passive recruitment strategies, active recruitment strategies use richer communication media (e.g., face-to-face, phone). To overcome external recruiting barriers, scholars suggest that small businesses should engage in these active recruitment practices, such as attending career fairs, to increase awareness (Williamson et al., 2002).

Internal and external recruitment strategies that use richer communication media, such as job fairs, interns, and employee referrals, are more capable of providing potential recruits with additional or hands-on knowledge. Also, due to an increase in two-way communication, more recruitspecific information is available to potential employers (Allen et al., 2004). Taking the time to participate in active recruiting can also help develop external networks, enhance social capital (Dubos, 2017), and lead to developing human capital via access to high-quality personnel (Coleman, 1988). Furthermore, active recruitment may produce more employment team diversity, which is proposed as a performance enhancer (Sequeria et al., 2018). Despite the potential benefits of active recruitment strategies, there is a dearth of research on active versus passive recruitment strategies, and there is even less related to small business recruitment. However, because active recruitment uses richer communication media and can help enhance organizational awareness and legitimacy in the eyes of job seekers, we hypothesize a positive relationship between small business performance and active recruitment.

Hypothesis 2: Higher-performing small businesses will engage in more active recruitment than lower-performing companies.

In exploring whether higher performing small businesses differ from lower performers in active recruitment, we hope to provide insight into small business' deeper approach to HR practices. When small businesses engage in active recruitment, as opposed to surface or passive recruitment, we propose they are engaged in HR practices at a deeper level. Evidence supporting Hypothesis 2 would suggest that small businesses applying HR depth would fall among higher performing companies.

\section{Methodology}

\section{Data Collection}

We administered a survey online through Qualtrics ${ }^{\circledR}$ to members of the Printing Industries of America (PIA), a trade association for printing companies. Multiple attributes of the printing industry make it an appropriate sample for this study. As the average PIA member has 47 employees, most printing companies are small businesses, addressing the small business focus here. Although we drew our data from one industry, printing companies are quite diverse, applying a wide variety of recent technological advances and offering a range of products and services, typically unique to each firm. In addition, as industry type may affect what HR approaches are adopted (Jackson et al., 1989), printing firms provide a somewhat generalized look as they offer a combination of products and services. Furthermore, PIA member firms yield a wide range of financial performance; $25 \%$ earn a net profit of $10 \%$ or more of revenue, yet the other $75 \%$ operate at profit breakeven or below. ${ }^{1}$ We hoped the potential performance variance in our sample would enhance findings related to how HR and recruitment activities differ between high performers and low performers.

Of the 3,238 PIA members who received an invitation to participate, 166 usable responses were obtained, resulting in a $5.13 \%$ response rate, which is relatively low. We attribute the low response rate to the length of the survey, which was comprised of approximately 140 items, due in part to a plethora of industry-related questions requested by PIA. Following the Small Business Administration's general small business definition of less than 500 employees, we eliminated one response from a firm with more than 500 employees. Respondents were C-level executives or senior management above the level of vice-president. In our sample, the average number of full-time employees was 65 , and annual sales averaged $\$ 13,409,701$.

\section{Measures}

Performance. Following previous research (e.g., Eddleston \& Kellermanns, 2007; Williams et al., 2018), we measured firm performance with self-reported perceptual items, which are typically highly correlated with absolute measures of firm performance (Honig \& Samuelsson, 2012; Shepherd \& Wiklund, 2009). Using a 7-point Likert scale ranging from 1- "much worse" to 7- "much better", our respondents assessed their firms' financial performance relative to regional competitors in eight areas over the last year. Cronbach's Alpha for firm performance was 0.94.

To group our sample of 166 printing firms into high performers and low performers, we applied hierarchical cluster analysis, employing the Wards method and Squared Euclidean distances for measure (Hair et al., 1998). As our eight performance survey items employed the same 7-point Likert scale, we chose not to standardize the data. Our cluster analysis produced two groups: 59 companies considered 
Table 1. ANOVA results for our eight performance measurement items

\begin{tabular}{|c|c|c|}
\hline Items & $F$ tests & $\begin{array}{l}\text { Significance of } \\
F\end{array}$ \\
\hline 1. Relative to competitors in our region, my business' growth in sales is... & $\begin{array}{l}F(1,164)= \\
150.91\end{array}$ & $p<.001$ \\
\hline 2. Relative to competitors in our region, my business' growth in profitability is... & $\begin{array}{l}F(1,164)= \\
156.21\end{array}$ & $p<.001$ \\
\hline 3. Relative to competitors in our region, my business' growth in market share is... & $F(1,164)=94.54$ & $p<.001$ \\
\hline $\begin{array}{l}\text { 4. Relative to competitors in our region, my business' growth in number of employees } \\
\text { is... }\end{array}$ & $F(1,164)=43.87$ & $p<.001$ \\
\hline 5. Relative to competitors in our region, my business' return on equity is... & $\begin{array}{l}F(1,164)= \\
203.56\end{array}$ & $p<.001$ \\
\hline 6. Relative to competitors in our region, my business' return on total assets is... & $\begin{array}{l}F(1,164)= \\
244.10\end{array}$ & $p<.001$ \\
\hline $\begin{array}{l}\text { 7. Relative to competitors in our region, my business' net profit margin (return on sales) } \\
\text { is... }\end{array}$ & $\begin{array}{l}F(1,164)= \\
157.26\end{array}$ & $p<.001$ \\
\hline $\begin{array}{l}\text { 8. Relative to competitors in our region, my business' ability to fund growth from profit } \\
\text { is... }\end{array}$ & $\begin{array}{l}F(1,164)= \\
187.69\end{array}$ & $p<.001$ \\
\hline
\end{tabular}

$F($ degrees of freedom $)=F$ value

higher performers, and 107 companies deemed lower performers. We then ran ANOVA and found the two clusters were different at a statistically significant level: The two clusters represent groups differing in performance. However, firms in each group are similar in performance. Table 1 provides a list of the eight performance items with the ANOVA analysis for those items.

HR practices. We assessed HR practices via Wright and colleagues' (2005) nine-item measure. This measure assesses nine specific HR practices that fall under four broad categories: namely selection, training, pay-for-performance and performance evaluation, and participation. The set of HR practices related to selection, pay-for-performance and performance evaluation, and participation were preceded by the following question, "For how many of your current employees are the following statements applicable?" Sample statements include, "Qualified employees have the opportunity to be promoted to positions of greater pay and /or responsibility within the company," "Employees in this organization regularly (at least once a year) receive a formal evaluation of their performance," and "Employees at this organization have a reasonable and fair complaint process." Responses were reported using a 5-point scale ranging from 1- "none” to 5- "all." Responses were recoded into a dichotomous yes/no response format where 1 and $2=$ no and 3 , 4 , and $5=$ yes. For training, participants were asked the open-ended question, "On average, how many hours of training do your employees receive each year?” We recoded the responses into a dichotomous yes/no response format utilizing the same approach applied by Wright and colleagues (2005). Specifically, responses greater than 15 hours were coded as a $1=$ yes and below 15 hours were coded as a 0 $=$ no. Consistent with Wright and colleagues (2005), we then used an additive index of all nine HR practices.

Active Recruitment. We created an active recruitment measure that includes three sources: career fairs, employee referrals, and internships. We were specifically interested in investigating these media-rich recruitment sources because they require more personal involvement by the organization in the recruitment process and allow for two-way communication between the organization and job seekers. These three active recruitment sources were couched within a broader set of eleven active and passive recruitment sources that are commonly utilized (e.g., newspaper postings, social media postings, job search websites, company websites, temporary employment agencies, permanent employment agencies, partnering with high schools, and partnering with colleges). To assess this measure, we asked the participants, "To what extent do you use the following recruitment sources?" Responses were recorded using a 5-point scale ranging from 1- "Do not use" to 5- "Always use." We recoded the responses into a dichotomous yes/no response format where 1 and $2=$ no and 3,4 , and $5=$ yes and then used an additive index for our three active recruitment sources.

\section{Results}

Means and standard deviations are presented in Table 2. To assess whether our 59 higher-performing businesses engaged in more HR practices and more active recruitment strategies than our 107 lower-performing businesses, we first ran a MANOVA using SPSS. Results indicated that there was a statistically significant difference in these HR activities based on level of business performance, $F(2,163)=5.35$, $p=.006$; Pillai's Trace $=.06, \eta_{\mathrm{p}}^{2}=.06$. To determine how HR practices and HR active recruitment differ for higher and lower-performing businesses, we examined the betweensubjects effects for each variable using ANOVA. For HR practices, results indicated that higher-performing companies engage in more HR practices than lower-performing companies $F(1,164)=7.36, p=.007, \eta_{p}{ }^{2}=.04$. However, we noted that for our HR practices outcome variable, the Levene's test for examining equality of variances was signifi- 
Table 2. Means and Standard Deviations for HR Practices and Active Recruitment

\begin{tabular}{lccc|ccc}
\hline & \multicolumn{3}{c}{ HR Practices } & \multicolumn{3}{c}{ Active Recruitment } \\
\cline { 2 - 7 } & Mean & SD & $n$ & Mean & SD & $n$ \\
\hline Higher Performing Businesses & 6.68 & 1.24 & 59 & 1.86 & 0.84 & 59 \\
Lower Performing Businesses & 5.94 & 1.86 & 107 & 1.53 & .080 & 107 \\
\hline
\end{tabular}

$S D$ : Standard Deviation; $n$ : number of businesses

Table 3. Results of MANOVA and ANOVA for hypothesis testing

\begin{tabular}{llr}
\hline Analysis procedure & $F$ tests & Significance of $F$ \\
\hline MANOVA & $F(2,163)=5.35$ & \\
\hline ANOVA & $F(1,164)=7.36$ & $p=.007$ \\
\hline HR Practices & $F(1,164)=6.26$ & $p=.013 \quad$ \\
Active Recruitment & & \\
\hline
\end{tabular}

$F($ degrees of freedom $)=F$ value

cant, denoting that we had failed this assumption. As such, to validate our findings, we also ran a Mann-Whitney test. Results indicated that our higher-performing businesses had a significantly $(p<.05)$ higher mean rank (93.64) than our lower-performing businesses (77.91), providing support for Hypothesis 1. For active recruitment, our results indicated that higher-performing businesses engaged in more active recruitment practices than lower-performing businesses $F(1,164)=6.26, p=.013, \eta_{\mathrm{p}}^{2}=.04$. Thus, Hypothesis 2 was also supported. A summary of the MANOVA/ ANOVA results are presented in Table 3.

\section{Conclusions}

Although researchers have found that high-performing organizations engage in more HR practices that enhance performance (Wright et al., 2005), it remains unclear whether these results extend to smaller businesses. Leaders of small businesses wear many hats and must prioritize which hats are more important and how much time to spend on those responsibilities (Williams et al., 2018). Often, this means that many HR practices receive less attention because of other priorities or a lack of knowledge on how to effectively carry out these responsibilities. As such, we sought to add to the existing research and investigate whether higher performing small businesses engage in more HR practices (the breadth of application) and active recruitment (the depth of HR application) than lower-performing firms.

Consistent with our predictions, we found that higherperforming small businesses engage in more HR practices and more active recruitment strategies than lower-performing small businesses. These findings support the general literature's position that HR plays a role in organizational performance (Wright et al., 2005). We contend that our findings demonstrate that enacting HR practices and engaging in active recruitment strategies is a greater priority for higher- performing small businesses, and that lower-performing small businesses should consider what other HR practices they can utilize to add value to their particular organizations.

\section{Practical Implications}

Our study's lower-performing organizations engaged in fewer HR practices and less active recruiting strategies than their higher performing counterparts. Because HR practices include various functions related to selection, evaluation and pay, training, and participation, smaller firms should first take a broad perspective to consider which specific HR functions they may be overlooking or need to invest in (a breadth approach). Then, as they prioritize which HR functions may add value to their organization, they should analyze how they can best perform those HR functions to help enhance individual and firm performance and gain a sustainable competitive advantage (a depth approach). In terms of specific HR practices, we would recommend that small businesses begin by analyzing their current recruitment strategies and see how they may utilize more active recruitment strategies, such as attending career fairs, to help enhance awareness and legitimacy of their organization in the eyes of job seekers, as well as help them expand their pool of recruits. As for current employees, there is growing research on the importance of creating a high-performance work system (HPWS) by instituting specific HR practices like training and participation that focus on employee development and motivation (e.g., Way, 2002). Accordingly, we would recommend that organizations evaluate other HR practices that can enhance employee development and motivation. Lastly, research has shown that leader perception of HR effectiveness matter for the implementation and success of HR practices (Klaas et al., 2012). Accordingly, while smaller firms look to improve their HRM, by implementing additional practices or tweak- 
ing how they engage in current HR practices, we recommend that organizational leaders must champion and support those changes by communicating the importance of these changes.

\section{Future Investigations}

Indeed, small business HR research is vital and relevant, a path worthy of more travel. Our findings suggest higherperforming small businesses tend to have more HR breadth and depth than lower-performers. Therefore, future research might explore what moderates these relationships. Potential moderators might include the size of the small business, the amount of HR management experience among a firm's leaders, or a firm's age. Future research may also look at how an employee market might affect the relationship between active recruiting and firm performance - in areas where the demand for employees is high and the supply is low, is active recruitment better connected to higher performance? Also, in terms of active recruitment, many organizations are turning to social media, which can impact employer reputation (da Motta Veiga et al., 2019) and provide avenues to connect with both active and passive job seekers (Carpentier et al., 2019). Future research can look at whether companies passively use social media to simply post jobs or actively use it to recruit qualified job applicants. And last, future research may explore small business HR depth by exploring other HR practices other than active recruiting as was explored here.

\section{Study Limitations}

As stated above, we employed firms from one industry in our study, which may form a limitation. Yet, we hope the wide diversity in printing industry products and services mitigates potential biases. Our performance measures were subjective, not objective financial data. However, given the inconsistencies in small business accounting, the desire to avoid taxes, and the lack of standardized financial reporting (as in public companies), subjective measures have provided a viable alternative for small business performance measurement (Honig \& Samuelsson, 2012; Shepherd \& Wiklund, 2009). We note that our results do not indicate causation and that engaging in more HR practices may lead directly to higher performance - other factors may affect small business performance regardless of the extent small business leaders are engaging in HR practices. And last, we applied several HR practices to indicate HR breadth and active recruitment for HR application depth. Certainly, researchers may apply other tools to study the breadth and depth of small business HR usage. Despite these limitations, we hope our work provides insights for practitioners, contributes to the existing small business HR research, and spurs future research in this area. 


\section{REFERENCES}

Agarwala, T. (2003). Innovative human resource practices and organizational commitment: An empirical investigation. The International Journal of Human Resource Management, 14(2), 175-197. http s://doi.org/10.1080/0958519021000029072

Allen, D. G., Van Scotter, J. R., \& Otondo, R. F. (2004). Recruitment communication media: Impact on prehire outcomes. Personnel Psychology, 57(1), 143-171. https://doi.org/10.1111/j.1744-6570.2004.tb 02487.x

Ariani, D. W. (2013). The relationship between employee engagement, organizational citizenship behavior, and counterproductive work behavior. International Journal of Business Administration, 4(2), 46-56.

Aydogdu, S., \& Asikgil, B. (2011). An empirical study of the relationship among job satisfaction, organizational commitment and turnover intention. International Review of Management and Marketing, 1(3), 43.

Cardon, M. S., \& Stevens, C. E. (2004). Managing human resources in small organizations: What do we know? Human Resource Management Review, 14(3), 295-323. https://doi.org/10.1016/i.hrmr.2004.06.001

Carlson, D. S., Upton, N., \& Seaman, S. (2006). The impact of human resource practices and compensation design on performance: An analysis of family-owned SMEs. Journal of Small Business Management, 44(4), 531-543. https://doi.org/10.1111/ j.1540-627x.2006.00188.x

Carpentier, M., Van Hoye, G., \& Weijters, B. (2019). Attracting applicants through the organization's social media page: Signaling employer brand personality. Journal of Vocational Behavior, 115, 103326. https://doi.org/10.1016/j.jvb.2019.103326

Carroll, M., Marchington, M., Earnshaw, J., \& Taylor, S. (1999). Recruitment in small firms: Processes, methods and problems. Employee Relations, 21(3), 236-250. https://doi.org/10.1108/0142545991027308 $\underline{0}$

Chowdhury, S., \& Schulz, E. (2020). The levels of base pay and incentive pay used by small firms to compensate professional employees with general and specific human capital. Journal of Small Business Management, 1-31.

Coder, L., Peake, W. O., \& Spiller, M. S. (2017). Do high performance work systems pay for small firms? An intellectual capital building perspective. Journal of Small Business Strategy, 27(2), 13-35.

Coleman, J. S. (1988). Social capital in the creation of human capital. American Journal of Sociology, 94, S95-S120. https://doi.org/10.1086/228943

Cross, R. L. (1997). Leveraging intellect in a small business: Designing an infrastructure to support today's knowledge worker. Journal of Small Business Strategy, 8(1), 15-34. da Motta Veiga, S. P., Clark, B. B., \& Moake, T. R. (2019). Influence of job-dedicated social media on employer reputation. Corporate Reputation Review, 23(4), 241-253. https://doi.org/10.1057/s41299-019-0008 $\underline{3-\mathrm{Z}}$

Deepa, E., Palaniswamy, R., \& Kuppusamy, S. (2014). Effect of performance appraisal system in organizational commitment, job satisfaction and productivity. Journal of Contemporary Management Research, 8(1), 72.

Deshpande, S., \& Golhar, D. (1994). HRM practices in large and small manufacturing firms: A comparative study. Journal of Small Business Management, 32(2), 49-56.

Dubos, R. (2017). Social capital: Theory and research. Routledge.

Eddleston, K. A., \& Kellermanns, F. W. (2007). Destructive and productive family relationships: A stewardship theory perspective. Journal of Business Venturing, 22(4), 545-565. https://doi.org/10.1016/j.jb usvent.2006.06.004

Erickson, B. H. (2001). Good networks and good jobs: The value of social capital to employers and employees. In W. Lin, K. S. Cook, \& R. S. Burt (Eds.), Social Capital. Aldine de Gruyter.

Froelich, K. A. (2004). Attracting today's educated workforce: Opportunities and challenges for small business firms. Journal of Small Business Strategy, 15(2), 1-18.

Hair, J. F., Black, W. C., Babin, B. J., Anderson, R. E., \& Tatham, R. L. (1998). Multivariate Data Analysis. Prentice hall.

Heneman, H. G., \& Berkley, R. A. (1999). Applicant attraction practices and outcomes among small businesses. Journal of Small Business Management, 37, $53-74$.

Honig, B., \& Samuelsson, M. (2012). Planning and the entrepreneur: A longitudinal examination of nascent entrepreneurs in Sweden. Journal of Small Business Management, 50(3), 365-388. https://doi.org/10.1111/ j.1540-627x.2012.00357.x

Howart, J. (2013, August 22). Small business advice: How to recruit against large competitors for top talent. Washington Post. https://www.washingtonpos t.com/blogs/on-small-business/post/small-business-a dvice-how-to-recruit-against-large-competitors-for-t op-talent/2013/08/21/d48acd0e-0a8a-11e3-9941-671 1ed662e71_blog.html

Ireland, R. D., \& Webb, J. W. (2007). Strategic entrepreneurship: Creating competitive advantage through streams of innovation. Business Horizons, 50(1), 49-59. https://doi.org/10.1016/j.bushor.2006.0 6.002

Jackson, S. E., Schuler, R. S., \& Rivero, J. C. (1989). Organizational characteristics as predictors of personnel practices. Personnel Psychology, 42(4), 727-786. https://doi.org/10.1111/j.1744-6570.1989.tb 00674.x 
Jayawarna, D., Macpherson, A., \& Wilson, A. (2007). Training commitment and performance in manufacturing SMEs: Incidence, intensity and approaches. Journal of Small Business and Enterprise Development, 14(2), 321-338. https://doi.org/10.1108/ 14626000710746736

Kaymaz, K. (2011). Performance feedback: Individual based reflections and the effect on motivation. Business and Economics Research Journal, 2(4), 115-134.

Kemelgor, B. H., \& Meek, W. R. (2008). Employee retention in growth-oriented entrepreneurial firms: An exploratory study. Journal of Small Business Strategy, 19(1), 55-68.

Klaas, B. S., McClendon, J., \& Gainey, T. W. (2000). Managing HR in the small and medium enterprise: The impact of professional employer organizations. Entrepreneurship Theory and Practice, 25(1), 107-124. https://doi.org/10.1177/104225870002500109

Klaas, B. S., Semadeni, M., Klimchak, M., \& Ward, A.-K. (2012). High-performance work system implementation in small and medium enterprises: A knowledge-creation perspective. Human Resource Management, 51(4), 487-510. https://doi.org/10.1002/ hrm. 21485

Kotey, B., \& Slade, P. (2005). Formal human resource management practices in small growing firms. Journal of Small Business Management, 43(1), 16-40. https://d oi.org/10.1111/j.1540-627x.2004.00123.x

Lai, Y., Saridakis, G., \& Johnstone, S. (2017). Human resource practices, employee attitudes and small firm performance. International Small Business Journal, 35(4), 470-494. https://doi.org/10.1177/02662426166 $\underline{37415}$

Lowry, J. R., \& Chapman, J. D. (2000). Critical business problems and advisors. Journal of Small Business Strategy, 11(1), 64-73.

Mahto, R. V., Ahluwalia, S., Khanin, D., \& Walsh, S. T. (2018). Financial performance enhancing strategies: Small family firms vs. small non-family firms. Journal of Small Business Strategy, 28(3), 18-30.

Markos, S., \& Sridevi, M. S. (2010). Employee engagement: The key to improving performance. International Journal of Business and Management, 5(12), 89-96.

Motley, C. (2016). How to take your recruiting strategy from passive to active. https://directemployers.org/201 6/03/23/take-recruiting-strategy-passive-active/

Patel, P. C., \& Cardon, M. S. (2010). Adopting HRM practices and their effectiveness in small firms facing product-market competition. Human Resource Management, 49(2), 265-290. https://doi.org/10.1002/ $\underline{\text { hrm.20346 }}$

Peake, W. O., Barber, D., III, McMilan, A., Bolton, D. L., \& Coder, L. (2019). Do management control systems stifle innovation in small firms? A mediation approach. Journal of Small Business Strategy, 29(2), $1-21$.

Phillips, B. D., \& Wade, H. (2008). Small Business Problems \& Priorities. NFIB Research Foundation.
Russ, F. A., \& McNeilly, K. M. (1995). Links among satisfaction, commitment, and turnover intentions: The moderating effect of experience, gender, and performance. Journal of Business Research, 34(1), 57-65. https://doi.org/10.1016/0148-2963(94)00042-d

Schultz, E. B., Bennett, N., \& Ketchen, D. J., Jr. (1997). An examination of the relationship between strategy and human resource management practices among small businesses. Journal of Small Business Strategy, 8(1), 35-48.

Sequeria, J. M., Weeks, K. P., Bell, M. P., \& Gibbs, S. R. (2018). Making the case for diversity as a strategic business tool in small firm survival and success. Journal of Small Business Strategy, 28(3), 31.

Shepherd, D., \& Wiklund, J. (2009). Are we comparing apples with apples or apples with oranges? Appropriateness of knowledge accumulation across growth studies. Entrepreneurship Theory and Practice, 33(1), 105-123. https://doi.org/10.1111/j.1540-6520.2 008.00282.X

Ulrich, D., \& Brockbank, W. (2005). The HR value proposition. Harvard Business Press.

Wade, H. (2016). Small business problems and priorities. National Federation of Independent Business Research Foundation. https://www.nfib.com/assets/NFIB-Probl ems-and-Priorities-2016.pdf

Way, S. A. (2002). High performance work systems and intermediate indicators of firm performance within the US small business sector. Journal of Management, 28(6), 765-785. https://doi.org/10.1177/01492063020 2800604

Whitman, D. S., Van Rooy, D. L., \& Viswesvaran, C. (2010). Satisfaction, citizenship behaviors, and performance in work units: A meta - analysis of collective construct relations. Personnel Psychology, 63(1), 41-81. https://doi.org/10.1111/i.1744-6570.200 9.01162.x

Williams, R. I., Jr., Manley, S. C., Aaron, J. R., \& Daniel, F. (2018). The relationship between a comprehensive strategic approach and small business performance. Journal of Small Business Strategy, 28(2), 33-48.

Williamson, I. O., Cable, D. M., \& Aldrich, H. E. (2002). Smaller but not necessarily weaker: How small businesses can overcome barriers to recruitment. Managing People in Entrepreneurial Organiztions, 5, 83-106. https://doi.org/10.1016/s1074-7540(02)0500 $\underline{5-5}$

Wright, P. M., Gardner, T. M., Moynihan, L. M., \& Allen, M. R. (2005). The relationship between HR practices and firm performance: Examining causal order. Personnel Psychology, 58(2), 409-446. https://doi.org/ 10.1111/j.1744-6570.2005.00487.x

Yamazakia, Y., \& Petchdee, S. (2015). Turnover intention, organizational commitment, and specific job satisfaction among production employees in Thailand. Journal of Business and Management, 4(4), 22-38.

Zottoli, M. A., \& Wanous, J. P. (2000). Recruitment source research: Current status and future directions. Human Resource Management Review, 10(4), 353-382. https://doi.org/10.1016/s1053-4822(00)00032-2 